UDK 782.8(436)"1885"(091)

929 Marija Terezija , austr. carica 929 Strauss, Johann, ml.

Primljeno: 4. 5. 2018.

Prihvaćeno: 24. 10. 2018.

Izvorni znanstveni rad

DOI: $10.22586 /$ pp.v55i0.83

Anna G. Piotrowska*

\title{
The Gypsy Baron (1885) as a musical monument remembering Maria Theresa? Facts, issues, controversies
}

The paper shows how Maria Theresa's legacy was remembered and highlighted already in the late $19^{\text {th }}$ century within the realm of musical culture. Focusing on the genre of operetta and taking The Gypsy Baron (1885) by Johann Strauss II (1825-1899) as an example the paper touches upon the issues of propaganda and collective memory as conjured up by musical theatre. Considered 'a musical monument to the Austro-Hungarian Empire' The Gypsy Baron (originally Der Zigeunerbaron) ultimately reveals the position the "King" Maria Theresia cherished in the $19^{\text {th }}$ century Empire, being at the same time a fine example of the legacy of her politics. The pillars of the operetta's plot are wars fought by Austrians: the Austro-Turkish War and the War of the Austrian Succession (1740-1748). The operetta is clearly the work inscribed into the specific political situation of the late $19^{\text {th }}$ century and constituted a musical response to concrete needs stimulated by civil attitudes. Hence the situation depicted in The Gypsy Baron reflects the multi-ethnic diversity of Habsburg Empire and the operetta's overall message is to glorify the cooperation between various nations as (supposedly) facilitated under Maria Theresa's reign.

Keywords: Maria Theresa, operetta, The Gypsy Baron (1885), Austro-Hungarian Empire, European musical culture

The chapter argues that Maria Theresa's legacy was not only remembered, but already mythologized in the late $19^{\text {th }}$ century within the realm of musical culture. The focus of the paper is on the operetta Der Zigeunerbaron (The Gypsy Baron) of 1885 as a representative work directly, but also, perhaps even more importantly,

Anna G. Piotrowska, Institute of Musicology, Jagiellonian University, ul. Westerplatte 10, 33-332 Kraków, Poland, E-mail: agpiotrowska@interia.pl 
in a more allusive way referring to the figure of the Empress. ${ }^{1}$ It is claimed that The Gypsy Baron can be described as a typical work attesting to what degree Maria Theresa's heritage not only influenced opera or operetta stage, but also deeply infiltrated popular imagination. Treating The Gypsy Baron as an illustration case study, in this text it is furthermore suggested that although the world of operetta might be overlooked or underestimated when discussing the role of political propaganda and the issues of collective memory, it should be recognized as one of the key sites employed to promote the Habsburg vision of their Empire.

I claim that - although in a veiled manner - The Gypsy Baron ultimately reveals the position the "King" Maria Theresa cherished in the $19^{\text {th }}$ century Empire, being at the same time a fine example of her politics' legacy. The framework of the operetta's plot hinges on the wars fought by Austrians in the $18^{\text {th }}$ century. The first one - the Austro-Turkish War, is merely alluded to in the operetta in the talk mentioning the Battle at Belgrade, during which one of the chief heroes of the work had supposedly been killed. Year later, his miraculous reappearance causes additional complications affecting the destiny of several protagonists. The second war mentioned in the operetta, which turns out of more importance for its dramaturgy, is the War of the Austrian Succession (1740-1748). It is, indirectly yet persuasively, suggested that when Maria Theresa found herself in need (believed to be ineligible to inherit the Habsburg throne), it was the multi-ethnic army that ultimately helped her claim her position. Yet, in The Gypsy Baron not only the references to the actual wars seem of relevance, though. In this chapter I suggest that - while reading between the lines and looking beyond the plot - in that operetta one can also sense other "wars" wedged by Maria Theresa. I specially refer here to the educational campaigns against superstitions and irrational beliefs that Maria Theresa fervently advocated. Indeed, The Gypsy Baron presents several Gypsy heroes who often fell prey to prejudices: in the operetta they are, accordingly, pictured as surrounded by the aura of mysticism and mystery. But eventually they turn out to be loyal and trustworthy citizens of the Empire. In that respect The Gypsy Baron can serve as a memento of Maria Theresa and her ministers' legacy, especially their "wars" against ignorance and superstitions.

Finally, the operetta proves how highly esteemed Maria Theresa was in the late 19th century as her name appears only in the most positive contexts: she is mentioned as a good and compassionate ruler, the one ennobling the just citizens, etc. Although not appearing on the stage herself, the queen is, however, always present for one of the main protagonists of the operetta - Saffi (allegedly of Gypsy origin) finds herself in the situation resembling Maria Theresa's position at the beginning of her reign. Hence, I would like to forward the hypothesis that Maria Theresa is, indirectly, represented by Saffi whose fortunes can be compared

\footnotetext{
Maria Theresa was also introduced (in a speaking role) in Nico Dostal's 1939 operetta Die ungarische hochzeit.
} 
with Empress's fate (especially her struggles to claim her inheritance). Ignored, even disregarded by others, Saffi turns out to be of aristocratic ancestry and all her prerogatives can be rightfully proved. Never openly articulated in the operetta, the haunting parallelism between Maria Theresa and Saffi (concerning their recognition as legal heirs) should be acknowledged as yet another proof of the long-lasting impact of the Empress on the cultural life of the Habsburg domain.

\section{The origins of the work: the context}

One of the most loved European operettas ${ }^{2}-$ The Gypsy Baron premiered on $24^{\text {th }}$ of October 1885 in the Theater an der Wien and was an instant success of its composer Johann Strauss II (1825-1899) and the librettist Ignaz Schnitzer (1839-1921). Their intention was to create the work inscribed into the specific political circumstances following the Compromise (Ausgleich) of $1867 .{ }^{3}$ Received with huge acclaim, bordering with wild enthusiasm, The Gypsy Baron came to represent a musical rapprochement between various nationalities of the Empire. ${ }^{4}$ Hence The Gypsy Baron -considered as "a musical monument to the Austro-Hungarian Empire" - can be understood as an immediate response to the concrete need of stimulating civil attitudes so desired within the dual Empire populated not only by Austrians, or Hungarians, but also Romanians, Germans, Slovaks, Serbs, Croats, Ruthenians and so called others, including Jews and Gypsies. ${ }^{6}$ The operetta narrates the story of their encounters (especially those between Hungarians, Austrians, and Gypsies, Jews, etc.): initially rather hostile, gradually their relations become very close, even friendly. Conceived in particular political circumstances The Gypsy Baron not only directly reflected the multi-ethnic diversity of the Empire, but also aimed at underlining the possibility of cooperation between so many various nations as (supposedly) facilitated already during Maria Theresa's reign. That reminder seemed crucial in the second half of the $19^{\text {th }}$ century, i.e. the times when "the matter of nationality was to be of a leading significance for the history of the region." ${ }^{7}$ Hence the $18^{\text {th }}$ century history - in spite of numerous wars led at that time - was shown in the operetta as the period filled with ethnic

\footnotetext{
2 Richard Traubner, Operetta. A Theatrical History (New York: Routledge, 2003), 129.

3 More on the context of the operetta's origin see: Anna G. Piotrowska, Gypsy Music in European Culture: from the late eighteenth to the early twentieth century (Boston: Northeastern University Press, 2013), 136-144.

4 Robert Ignatius Letellier, Operetta: A Sourcebook, vol. I (Newcastle: Cambridge Scholars, 2015), 497.

5 Traubner, Operetta. A Theatrical History, 111.

6 Andras Gergely, Zoltan Szasz, Kiegyezes utan (Budapest: Gondolat Kiado, 1978), 111.

7 Tadeusz Kopyś, Kwestia narodowościowa na ziemiach Korony świętego Stefana w latach 1867-1918 (Kraków: Promo, 2001), 129.
} 
intermingling that undeniably must have resulted in strengthening of the multinational Empire. As Camille Crittenden wrote: "Premiered at a time of growing political and economic tensions, Der Zigeunerbaron propagates an idealized view of Hungarian satisfaction with its role in the monarchy and perpetuates longstanding national tensions within the divided empire." ${ }^{8}$ It is clear that The Gypsy Baron, as many other operettas of that time, openly endorsed official efforts to create the image of the happily united state. In the journal Das Vaterland from 1910 one could read a volume speaking characteristics of The Gypsy Baron boasting that "on account of the text, but even more on account of the music, it is a national, patriotic, a true Austria and Viennese work of classical character." 9 The appeal of the operetta was located predominantly in its music, but also connected with several audience-pleasing elements, including its festive diversity displayed in colorful costumes and vivid dances.

It can be argued that political aims of the late $19^{\text {th }}$ century were truly fulfilled in some operettas being cultural productions actively duplicating officially approved public images, and thus engaged in the processes of legitimizing the ruling power. ${ }^{10}$ The complicated $18^{\text {th }}$ century history was recast on the operetta stage for updated goals, predominantly to praise the protective Austrian hegemony over the whole state. In operettas like The Gypsy Baron, the Habsburg history was retold (to some degree also reinvented) in such a way that it could support the Empire's (self)consciousness of its glorious past.

\section{Love story in the times of war}

The Gipsy Baron is based on a short tale originally written by a respected Hungarian author Mór Jókai (1825-1904). Strauss became acquainted with the novella entitled Saffi (published in 1883) through his third wife, Adela Deutsch. The Hungarian journalist Schnitzer helped him to craft the text of the libretto. The operetta's plot is basically quite simple, being a romantic love story not devoid of elements of mystery and adventure. The action is set in the mid-18th century, during the reign of Maria Theresia. The hero - Sándor Barinkay, whose family had been expelled and sent into exile in Turkey - comes back to reclaim his, alas ruined, inheritance. The new neighbor of his ancestral lands - a Hungarian pig farmer called Kálmán Zsupán who wants to appropriate the requested grounds, proposes a perfect solution to this unexpected (to him) situation. He suggests

\footnotetext{
8 Camille Crittenden, 'Durch eine Straußische Operette war man eins geworden: Austro-Hungarian Relations and „Der Zigeunerbaron', Modern Austrian Literature 32 (1999), no. 3: 65.

9 See: Das Vaterland, 27th December 1910. Quoted after: Crittenden, Johann Strauss and Vienna. Operetta and the Politics of Popular Culture, 170.

10 See: Peter Scobadi (ed.), Politische Mythen und nationale Identitäten im (Musik-)Theater: Vorträge und Gespräche des Salzburger Symposiums 2001, vol. 2 (Anif/Salzburg: Mueller-Speiser, 2003).
} 
that Barinkay should marry his daughter Arsena. Much to everybody's surprise, the girl reacts reluctantly to this seemingly ingenuous plan, being - as it turns out - in love with Ottokar, the son of her own governess, Mirabella. Arsena declares that she will marry only an aristocrat, for example a baron. Feeling disappointed and ridiculed, instead of Arsena Barinkay decides to marry a Gypsy girl - Saffi, who gives him no such conditions. Furthermore, the band of Gypsies recognizes Barinkay as their lawful ruler and dubs him a 'Gypsy Baron'. They pledge him eternal loyalty, remembering the kind attitude they had experienced from Barinkay's family. Mysterious Czipra, who is taking care of Saffi, discloses to everyone that Barinkay's late father always protected despised Gypsies, for example by allowing them to camp on his lands. Regrettably, Barinkay's father fortunes had changed when he had fallen into ill favour as a result of the collaboration with Turks. It is also recalled that when the Turks still controlled the neighbourhood, the treasure was hidden in this area and Czipra, being a fortune-teller, encourages the young couple (Barinkay and Saffi) to search for it. In the meantime, Count Homonay appears recruiting for the wars and the treasure is confiscated for the needs of the army. Additionally, it is revealed that Saffi is far from being Czipra's own daughter. Although the girl adopted the value system of her Gypsy protectors, in fact she is of noble birth. Now, Barinkay feels obliged to prove that he deserves his aristocratic wife, especially as their Gypsy-law marriage is announced illegal. Along with other men he enrolls into the army and they all end up going off to the war. Their triumphant return some time later - already after the victorious battle - reunites enamoured couples: Arsena and Ottokar, Saffi and Barinkay. It is in Vienna where they all celebrate the successful campaign and their promising future under Maria Theresa's protectorate.

As explicitly noted in several opera and operetta guides The Gipsy Baron shows a very telling trajectory: it begins outside the bourgeois salon, among the Gypsies, and ends in Maria Theresa's Vienna. ${ }^{11}$ It truly exploits "the immense possibilities of the combination of Maria Theresa's baroque era and the gypsy milieu." ${ }^{2}$ Especially the final act, which presents the charms of Maria Theresa's Vienna, serves as an expressive symbol: the transition from an impoverished province to the glamorous capital city may be read as an illustration of the situation of the whole Empire, well developing and enhancing. Furthermore, not only is Barinkay pardoned and ennobled by Maria Theresa, but in fact all citizens of the Empire can take part in the Viennese splendour, enjoying their good lives under the rule of the gentle queen. ${ }^{13}$

11 Joseph Wechsberg, The waltz emperors: the life and times and music of the Strauss family (New York: Putnam, 1973), 225.

12 Egon Gartenberg, Vienna; its musical heritage (University Park, Pennsylvania State University Press, 1968), 165.

13 Anton Mayer, Rita Steblin, Johann Strauss: a nineteenth century pop-idol (Wien: Böhlau, 1999), 193. 


\section{In the shadow of the real wars}

Hungarian historian Péter Hanák rightly observed that what adds "the piquancy" to this - otherwise quite simple - story, is the fact that its numerous elements were based on the real life. ${ }^{14}$ Hence, The Gypsy Baron introduced several down-to-earth, rather serious, topics including the effects of wars on human existence. A few military events, although merely referred to in the course of the operetta, drastically influence the destiny of the heroes. In the operetta the Turkish presence seems of the primary relevance, especially their attempts to conquest central territories of Europe. We learn, for example, that Barinkay's father was suspected of collaborating with the Turks and, as a result of the accusation, forced to leave his homeland. Obviously, he shared his destiny with many other migrating people (especially those inhibiting the Balkans) who contributed to the intermingling of nations at that time. As another catalyst of the operetta's plot appears the Seventh Ottoman-Venetian War (1714-1718). Although it took place more than 20 years before the action of The Gypsy Baron begins, it is immediately revealed that during the Siege of Belgrade one of the heroines, the governess Mirabella was separated from her spouse. Left with an infant son Ottokar, believing her beloved to be dead, she raised her son on her own. When the governess is talking about her misfortune past, the orchestral accompaniment suggests Turkish-styled sounds (in the percussion section), alluding to the defeat of the Ottomans by Austrian troops in the summer of 1717. Eventually, Mirabella finds home at Zsupan's place, where Ottokar falls in love with the pig-breeder's daughter, Arsena. On the arrival of Barinkay, all relations between young people become complicated. It also turns out that Barinkay's companion - Conte Carnero, Commissioner for Oaths, is in fact Ottokar's long-lost father and Mirabella's supposedly killed husband. Hence - although not shown directly in the operetta - the Siege of Belgrade seems crucial for the protagonists and influences the meanders of their lives, impacting also their friends and relatives.

But while the past war between the Turks and Austrians is merely alluded to in the operetta, the so-called War of the Austrian Succession becomes actually the pretext to present the colourful tradition of enrolment as cultivated in the terrains of the Empire; it also enables the final resolution of several conflicts. The mentions of the War appear several times: for example, in the second act we are told that the War dragged on many fronts: "Our fatherland is in need! Bavaria, Italy, France and Spain would dispute our Queen's rights in Spain."15 Barinkay, Ottokar, Zsupan and others are urged to fight against Spanish troops determined

\footnotetext{
14 Péter Hanák, The Garden and the Workshop: Essays on the Cultural History of Vienna and Budapest (Princeton, N. J.: Princeton University Press, 1999), 138.

15 George Jellinek, History Through the Opera Glass: From the Rise of Caesar to the Fall of Napoleon (New York; London: Pro/Am Music Resources; Kahn \& Averill, 1994), 256.
} 
to reinforce Spanish position in the northern Italy by competing with Austrian dominance in the region. In order to reclaim Habsburg territory, Maria Theresa's army needs to be strengthened: in the operettas we are reminded that it accepted all soldiers - Austrians, Hungarians, as well Gypsy or Jewish. In the second act the whole recruitment scene is featured. Barinkay 's friend - Count Peter Homonay, arrives with his hussars, seeking volunteers to fight against the Spaniards. As a part of the grand finale Homonay sings his encouraging song, followed by a stirring czardas. The recruitment scene is modelled upon authentic customs cultivated in the Empire, when many reassuring and heartening words were said, and Gypsy bands played dance music to entertain the recruits deciding to join the army. In the operetta it is Zsupan and Ottokar who eventually enlist in the multi-ethnic army. Also, Barinkay feels in need to prove himself in the military service. Everyone is joining in the celebration, as the War seems to promise solutions to so many burning problems - be it of financial or romantic nature.

The Gypsy Baron in not unique in making references to the War of Austrian Succession in the musical realm. It was also featured in other musical productions, serving, for example, as a background for 1862 opera by Giuseppe Verdi La forza del destino [The Power of Fate or The Force of Destiny] with libretto by Francesco Maria Piave. Its plot was set in the mid- $18^{\text {th }}$ century Spain and Italy: two heroes of the opera - Don Alvaro and his companion Don Carlo took part in the Battle of Velletri, which occurred on $12^{\text {th }}$ of August 1744. Also, in the beginning of the $20^{\text {th }}$ century the potential of depicting the charms of Vienna in 1740s (the first years of Maria Theresa's reign) was seized by Richard Strauss in his 1911 comic opera Der Rosenkavalier [The Knight of the Rose or The Rose-Bearer], Op. 59, after libretto by Hugo von Hofmannsthal.

\section{In the shadow of virtual wars}

On a symbolic level The Gypsy Baron represents Maria Theresa's attempts to fight with superstitions and magic. Her reign is immortalized in the operetta as a fundamentally turning point for the reception of those "untameable and unrestrictable: the Gypsies of the Balkans, the 'link' group between Ottoman and Habsburg empires." ${ }^{16}$ As commonly known the Empress - acting in the spirit of Enlightenment - issued several edicts aiming at 'civilizing' the Gypsies; she was also actively involved in combating beliefs in supernatural phenomena such as vampires. The Gypsy Baron proves to what extend Maria Theresa's efforts were already deeply rooted in the memory of the late $19^{\text {th }}$ century society, as the operetta's development clearly indicates that initial prejudices against Gypsies and sorcery can be overtaken when facts are better known.

16 William O’Reilly, “Conceptualizing America in Early Modern Central Europe”, Pennsylvania History: A Journal of Mid-Atlantic Studies 65 (1998): 105. 
Already in the very title of Strauss's crowning work, the composer makes use of Gypsy sentiments; moreover, the Gypsies are presented in the operetta as an integral part of the Empire. Although initially portrayed as social pariahs symbolizing the unknown, uncanny world, they are also depicted as law-abiding citizens and courageous soldiers contributing to the final success. ${ }^{17}$ It turns out that the Gypsies should not be feared of, but quite opposite - they might be even respected.

The colorful crowd of Gypsies as pictured in The Gypsy Baron continues the $19^{\text {th }}$ century operetta tradition of featuring heroes representing distant and mysterious peoples: in Offenbach's operettas that function was fulfilled by vagabonds, bandits and smugglers, ${ }^{18}$ but given over to Gypsies in Strauss's operetta. Such a position of Gypsies within the dramaturgical framework of The Gypsy Baron results in their stereotypical portrayal. Foremost, the Gypsies are presented as a collective against which two female figures stand out: the beautiful Saffi and Czipra as a wise old Gypsy woman, respected by Gypsies and non-Gypsies alike. ${ }^{19}$ Possessed by mysterious powers she obviously is able to tell fortunes, she reads cards and interprets prophetic dreams. Saffi (Czipra's alleged daughter) can be situated at the opposite pole. Quite stereotypically she turns out to be an aristocratic child merely brought up amongst the Gypsies. While still unaware of her true, i.e. non- Gypsy identity, Saffi expresses ambivalent judgements about her Gypsy companions in the song "So elend und so true." According to Camille Crittenden, the introduction of this song already in the first act of the operetta was necessary to justify the later change of the girl's fate. ${ }^{20}$ The song itself presents a list of - explicitly articulated - stereotypes and superstitions connected with Gypsies. The girl makes allusions to the thieving tendencies ascribed to Gypsies. ${ }^{21}$ She also warns against unstable Gypsy love, accusing Gypsies of unfaithfulness. The Gypsy love is strictly connected with the lack of moral rigours as supposedly observed among the Gypsies. In the operetta they are accused of "looser moral or sexual codes." 22 According to Crittenden showing Gypsies as sexually rampant could provide voyeuristic pleasures to Viennese audience and watching Gypsy (unmoral) courting on as presented onstage the public could still cherish their

\footnotetext{
17 Volker Klotz, Operette: Porträt und Handbuch einer unerhörten Kunst (Kassel: Bärenreiter, 2004), 39.

18 Klotz, Operette: Porträt und Handbuch einer unerhörten Kunst, 45.

19 In many Gypsy groups the so-called gody pchuri daj-a wise old woman enjoyed the greatest (next to the leader) respect and authority. See: Jerzy Ficowski, Cyganie polscy [Polish Gypsies] (Warsaw: Państwowy Instytut Wydawniczy, 1953), 15.

20 Crittenden, Johann Strauss and Vienna. Operetta and the Politics of Popular Culture, 187.

${ }^{21}$ On the sources of such a stereotype see: Ian Hancock, Introduction, in: David Crowe, John Kolsti (eds.), Gypsies of Eastern Europe (Armonk, N. Y. : M.E. Sharpe, 1991), 5.

22 Crittenden, Johann Strauss and Vienna. Operetta and the Politics of Popular Culture, 182.
} 
own (superficial) sense of moral superiority. ${ }^{23}$ This illusion seems to be underlined by a juxtaposition of two romantic rendezvous portrayed in the operetta: the non-Gypsy pair of Arsena and Ottokar versus (supposedly) Gypsy of Saffi and Barinkay. The non-Gypsy couple limit themselves to a stolen romantic meeting at an evening hour while the latter, despite the short duration of their acquaintance, succumb to the sexual fascination with each other and, with the permission of Czipra, spend a passionate night together. The inappropriateness of such a union appeared so extreme that at the time the operetta was to be performed the censor demanded that the relations of the couple Barinkay-Saffi be not [...] described in the text as a wild marriage but forbidden unlawful marriage. ${ }^{24}$

In the course of the operetta the audience is exposed to other stereotypes concerning Gypsies and reminded of their close links with the nature. In the song 'Als flotter Geist' from the first act, Barinkay spins the tale about his adventures in a far-away lands as a trainer of wild animals and an acrobat and magician. This immediately refers to the typical conceptualisations of Gypsies performing in wandering troupes, taming exotic animals, etc. ${ }^{25}$ Other occupations traditionally associated with Gypsies are also mentioned in the operetta (e.g. blacksmithing in the song "Ja, das Eisen wirdgefuge" from the second act). Furthermore, Gypsies are shown as the people following their own regulations and laws. For example, Barinkay is proclaimed to be the Gypsy baron even though he is not a genuine Gypsy: therefore, he is not so much a "Gypsy baron" but rather the "baron of the Gypsies." But Barinkay's recognitions by the Gypsy band, coupled with bestowing an aristocratic title, is a clear reference to a standing Gypsy tradition to elect their own leaders. ${ }^{26}$ Also very stereotypically are depicted the interactions between the Gypsies and non-Gypsies. Although the main emphasis pf the operettas is on the unity of the Empire, antagonistic relations between Gypsies and those outside their ethnic group are strongly highlighted. Towards the end of the first act Barinkay, rejected by Arsena and her family, is derided as a so-called "Gypsy baron" - being in that contest at least a defamatory term. In revenge for such a degrading treatment Barinkay decides to humiliate Arsena publically by declaring that instead of her he is about choose a Gypsy girl as his wife. This move is interpreted as an act of disrespect - affronting the family results in a violent exchange of views and consequently leads to an argument. However, in

23 Crittenden, Johann Strauss and Vienna. Operetta and the Politics of Popular Culture, 187.

24 Werner Jaspert, Johann Strauss. Sein Leben, sein Werk, seine Zeit (Berlin: Werkverlag BMBH, 1939),193.

25 The association of Gypsies with these activities was deeply rooted within the European tradition. See: Ficowski, Cyganie polscy, 76.

${ }^{26}$ Fifty years after the premier of The Gypsy Baron - i.e. in 1935, a self-proclaimed leader of the Gypsies, the headman Matejasz Kwiek, investing on himself the title of baron, appeared in Poland. See: Ficowski, Cyganie polscy, 66. 
the course of the operetta's plot the Gypsies gain the sympathy of the audience and finally are presented as noble people, who have found their place within the structures of the multi-ethnic monarchy.

Despite such a nice (eventually) picture of Gypsies, in reality attempts to reform them under the rule of Maria Theresa (and later her son Joseph II) were of particularly harsh character. Maria Theresa's policies against Gypsies were sometimes quite radical, as she "trudged long and stubbornly in her course, blind to the misery she caused and the utter futility of her efforts." ${ }^{27}$ As commonly known she issued a series of decrees with the intention to turn Gypsies into "new citizens," applying the politics of forced assimilation. Gypsy children were taken from their parents and put into the custody of non-Gypsies. Consonantly disproved and humiliated, living in dreadful conditions, the Gypsies managed to protect their unique identity paying the price of rejection and stereotypization: as shown in the operetta, even the denomination "Gypsy" preserved its distinctly derogatory implications awaking fixed, pejorative images. However, Maria Theresa's struggles and scholarly works on the Gypsies appearing in the late 18th century contributed also to the production of the romanticized image of the Gypsies - as free but honorable individuals. This aspect of their characteristics was reminded in The Gypsy Baron, alongside allusions to Maria Theresa'a attempts at eradicating (non only purely Gypsy) sorcery.

It is a well-known fact that the devout Empress needed to deal with disturbing rumours on vampirism appearing at the outskirts of her dominions. After yet another outbreak of the vampire panic gripping eastern parts of the Empire, Maria Theresa decided to intervene. She had her personal doctor, the Dutch-Austrian Gerard van Swieten, investigate the phenomenon. ${ }^{28}$ In his 1768 report Abhandlung des Daseyns der Gespenster [Discourse on the Existence of Ghosts], he presented scholarly explanation for these beliefs blaming credulity, imagination and ignorance among simple folks for causing distress. In order to call a halt to the vampire hysteria Maria Theresa passed laws prohibiting exhumations of graves as well as their possible desecration and mutilations..$^{29}$ Empress's war against superstitions and sorcery can be sensed, although only as an innuendo, in The Gypsy Baron. It is shown that Czipra's unnatural abilities can be, in fact, quite simply and reasonably explained: because of her old age she could easily remember a lot of things which she presented as visions or prophecies.

27 Konrad Bercovici, The story of the Gypsies (New York: Cosmopolitan Book Corp., 1928), 91.

28 Derek Hall, Roxanne Hellman, Vampire Legends and Myths (New York: Rosen Pub., 2012), 105.

29 Diane Bailey, Vampires in Mythology (New York: Rosen Central, 2012), 52. 


\section{Haunting parallelism: Saffi and Maria Theresa}

When the plot of The Gypsy Baron begins, twenty-something Maria Theresa, is already the ruler of the Empire. The war to secure her inheritance heavy influences the fate of the operetta's protagonists. Several, apparently minor events shown in the operetta can be explained by the war situation. For example, as the disorganized Austrian army needed military reforms, ${ }^{30}$ the confiscation of the treasure found by Saffi and Barinkay may be read as an allusion to the state of the army at that time. Also the position of Maria Theresa can be sensed in the operetta as similar to the situation of Saffi. Although raised by the Gypsies, Saffi is a real Ottoman princess entitled to the aristocratic title as a true daughter of the last Pasha of Temesvár. Similarly to Saffi - whose position in the social hierarchy is finally recognized and appreciated, Maria Theresa also overcomes obstacles. Her importance for the operetta is not only hidden in this haunting parallelism. In fact, she is mentioned several times in the course of action, and in some contemporary versions of The Gypsy Baron the figure of Maria Theresa is actually introduced onstage: the young Empress appears among noblemen in the audience hall of the Schönbrunn Palace. ${ }^{31}$

\section{Musical echoes of the wars}

The operetta The Gypsy Baron is deeply rooted in the Viennese musical tradition: both in respect to waltzes and introduction of Hungarian - Gypsy idiom (so called style hongrois). ${ }^{32}$ There are also a few moments which musically embed the The Gypsy Baron within war times. More specifically, it is the military recruiting scene in the finale to the second act, as well as the triumphant entrance march appearing at the beginning of the third act.

Furthermore, the shadow of Turkish dominance and wars against the Ottomans can be easily deducted in Turkish-sounding hints ("signifiers" - to use Scott's terminology), ${ }^{33}$ which are interwoven throughout the whole work. For the first time the heavy and noisy percussion evoking the Turkish style is heard when Arsena's

\footnotetext{
${ }^{30}$ Gunther E. Rothenberg, "The Habsburg Army in the Napoleonic Wars", Military Affairs 37 (Feb,1973), 1: 1 .

31 In 2010 the Japanese troupe Moon staged The Gypsy Baron in Takarazuka Grand Theatre and Tokyo Takarazuka Theatre introducing Maria Theresa as one of the heroes. See: http://www.takawiki.com/tiki-index.php?page $=$ The + Gypsy+Baron $+\% 2 \mathrm{~F}+$ Rhapsodic + Moon $+($ Moon +2010$)$ Accessed: 02/02/2017.

32 More on the style hongrois see: Jonathan Bellman, “Toward a Lexicon for the Style hongrois", The Journal of Musicology 9 (1991), no. 2: 214-237.

33 Derek B. Scott, From the Erotic to the Demonic: On Critical Musicology (New York: Oxford University Press, 2003), 158.
} 
governess - Mirabella narrates the dramatic story of her marriage. According to Lynn Hooker

"more significantly, the Gypsy characters are at times marked by Turkish [...] style. The fast section of Saffi's "Zigeunerlied" uses not only numerous Hungarian-Gypsy markers but also triangles and cymbals, which may be heard as "Turkish percussion". We might interpret this sonic reference as a hint of Saffi's true identity, which is not revealed until much later; but another number, for the entire Gypsy chorus, makes an even stronger connection between stage Gypsies and Turkish musical elements." 34

This type of simplified music-painting corresponds well with the musical situation of the Balkans heavily influenced by Turkish elements, where church and folk music was predominantly cultivated. ${ }^{35}$

\section{Expected and unexpected repercussions}

Given the simplicity of the plot, the presence of ear-catching tunes and references to exotic (i.e. Turkish and Gypsy) styles, The Gypsy Baron, was (as mentioned already) an instant and lasting success. Since its premiere it has been performed in Europe and all around the globe, proving not only to be one of Strauss's finest works, ${ }^{36}$ but - perhaps - also one of the best recognized operettas ever. Quite unsurprisingly then - also in light of the war context featured in the operetta - it was commemorated during the Second World War. The German anti-partisan operation carried out between May-June of 1944 in Soviet Union was tagged as "Zigeunerbaron." It involved six divisions which "cleared the rear areas of 9th Army and 2nd Panzer Army" in preparation for the operation "Zitadelle" (Citadel) - "the last big German offensive on the Eastern Front." 37

However, the operetta The Gypsy Baron has been mostly remembered and debated by the scholars as a musical work clearly embedded into the $19^{\text {th }}$ century Austro-Hungarian politics of reinforcing the legitimacy of the multi-ethnic Empire. One of its prominent subjects, composer Ernst Křenek (1900-1991) critically reflected on it in the middle of the $20^{\text {th }}$ century claiming that in the operetta

\footnotetext{
34 Lynn Hooker, "Turks, Hungarians, and Gypsies on stage: exoticism and auto-exoticism in opera and operetta", Hungarian Studies 27 (2013), no. 2: 301.

35 Miloš Velimirović, "Balkan music history in the seventeenth and eighteenth centuries. Introductory remarks", Revista de Musicología 16 (1993), no. 3: 1704.

36 Traubner, Operetta. A Theatrical History, 129. ("The score of the Gypsy Baron is generally rated Strauss's number two work, directly after Die Fledermaus").

${ }^{37}$ On Zigeunerbaron military action see among others: Simon Robbins, Dirty Wars: A Century of Counterinsurgency (Stroud: The History Press, 2016).
} 
"sentimentality reared its ugly head along with a distasteful folkloristic arrogance; this led to the habit of seeing the non-German speaking people of the Austrian monarchy as curious, laughable exotics, [...], of operetta, [...] As the same, everything is wrapped up in a phenomenal wealth of beautiful music which will always give these works a certain life even when they themselves are no longer interesting as memories of a great period - brilliant, sad and very strange." 38

These bitter words seem, nevertheless, to confirm the thesis that in musical productions of the late $19^{\text {th }}$ and early $20^{\text {th }}$ century composed and staged in the Empire the state was envisaged as the multi-national, powerful entity. It owed its many traditions to Maria Theresa's times, deeply indebted to her reign, and particularly fond of cherishing the memory of her victorious military and educational campaigns.

38 Ernst Křenek, "A Few Words About Johann Strauss", in: Ernst Křenek ed., Exploring Music. Essays by Ernst Křrenek (London: Calder and Boyars, 1966), 21-22. 


\section{Literature}

Bailey, Diane. Vampires in Mythology. New York: Rosen Central, 2012.

Bellman, Jonathan. "Toward a Lexicon for the Style hongrois". The Journal of Musicology 9 (1991), no. 2: 214-237.

Bercovici, Konrad. The story of the Gypsies. New York: Cosmopolitan Book Corp., 1928.

Crittenden, Camille. "Durch eine Straußische Operette war man eins geworden: Austro-Hungarian Relations and Der Zigeunerbaron”. Modern Austrian Literature 32 (1999), no. 3: 65-84.

Ficowski, Jerzy. Cyganie polscy [Polish Gypsies]. Warszawa: Państwowy Instytut Wydawniczy, 1953.

Gartenberg, Egon. Vienna; its musical heritage. University Park, Pennsylvania State University Press, 1968.

Gergely, Andras; Szasz, Zoltan. Kiegyezes utan. Budapest: Gondolat Kiado, 1978.

Hall, Derek; Hellman, Roxanne. Vampire Legends and Myths. New York: Rosen Pub., 2012.

Hanák, Péter. The Garden and the Workshop: Essays on the Cultural History of Vienna and Budapest. Princeton, N. J.: Princeton University Press, 1999.

Hancock, Ian. Introduction. In: Gypsies of Eastern Europe, eds. David Crowe, John Kolsti. Armonk, N. Y.: M. E. Sharpe, 1991.

Hooker, Lynn. "Turks, Hungarians, and Gypsies on stage: exoticism and auto-exoticism in opera and operetta”. Hungarian Studies 27 (2013), no. 2: 291-311.

Jaspert, Werner. Johann Strauss. Sein Leben, sein Werk, seine Zeit. Berlin: Werkverlag BMBH, 1939.

Jellinek, George. History Through the Opera Glass: From the Rise of Caesar to the Fall of Napoleon, New York; London: Pro/Am Music Resources; Kahn \& Averill, 1994.

Klotz, Volker. Operette: Porträt und Handbuch einer unerhörten Kunst. Kassel: Bärenreiter, 2004.

Kopyś, Tadeusz. Kwestia narodowościowa na ziemiach Korony świętego Stefana w latach 1867-1918. Kraków: Promo, 2001.

Křenek, Ernst. “A Few Words About Johann Strauss”. In: Exploring Music. Essays by Ernst Křenek, eds. Ernst Křenek, 19-22. London: Calder and Boyars, 1966.

Letellier, Robert Ignatius. Operetta: A Sourcebook, vol. I. Newcastle: Cambridge Scholars, 2015. 
Mayer, Anton; Steblin, Rita. Johann Strauss: a nineteenth century pop-idol. Wien: Böhlau, 1999.

O’Reilly, William. "Conceptualizing America in Early Modern Central Europe". Pennsylvania History: A Journal of Mid-Atlantic Studies 65 (1998): 101-121.

Piotrowska, Anna G. Gypsy Music in European Culture: from the late eighteenth to the early twentieth century. Boston: Northeastern University Press, 2013.

Robbins, Simon. Dirty Wars: A Century of Counterinsurgency. Stroud: The History Press, 2016.

Rothenberg, Gunther E. “The Habsburg Army in the Napoleonic Wars”. Military Affairs 37 (Feb, 1973), no. 1: 1-5.

Scobadi, Peter, ed. Politische Mythen und nationale Identitäten im (Musik-)Theater: Vorträge und Gespräche des Salzburger Symposiums 2001, vol. 2. Anif/Salzburg: Mueller-Speiser, 2003.

Scott, Derek B. From the Erotic to the Demonic: On Critical Musicology. New York: Oxford University Press, 2003.

Traubner, Richard. Operetta. A Theatrical History. New York: Routledge, 2003.

Velimirović, Miloš. "Balkan music history in the seventeenth and eighteenth centuries. Introductory remarks". Revista de Musicología 16 (1993), no. 3: 17031705.

Wechsberg, Joseph. The waltz emperors: the life and times and music of the Strauss family. New York: Putnam, 1973.

\section{Internet sources}

http://www.takawiki.com/tiki index.php?page=The+Gypsy+Baron+\%2F+Rhapsodic+Moon+(Moon+2010) (Accessed: 02/02/2017). 
Anna G. Piotrowska*

\section{Ciganski barun (1885.) kao glazbeni spomenik sjećanja na Mariju Tereziju? Činjenice, pitanja, kontroverze}

\section{Sažetak}

Smatrana "glazbenim spomenikom Austro-Ugarskoj Monarhiji," opereta Ciganski barun (izvorno Der Zigeunerbaron) iz 1885. godine Johanna Straussa II. (1825. - 1899.) otkriva položaj "kralja" Marije Terezije uvriježenog u društvenom sjećanju Austro-Ugarske Monarhije tijekom 19. stoljeća. Događaji koje prikazuje opereta izravno upućuju na ratna vremena iz vladavine carice Marije Terezije te ukazuju na njenu ulogu u multietničkoj državi kojom je vladala i upravljala. Opereta se može tumačiti kao glazbeni odgovor na konkretne potrebe Austro-Ugarske Monarhije krajem 19. stoljeća obzirom da je, referirajući se na kolektivnu memoriju slavne prošlosti, služila u svrhe propagande.

Ključne riječi: Marija Terezija, opereta, Ciganski barun (1885.), Austro-Ugarska Monarhija, europska glazbena kultura 